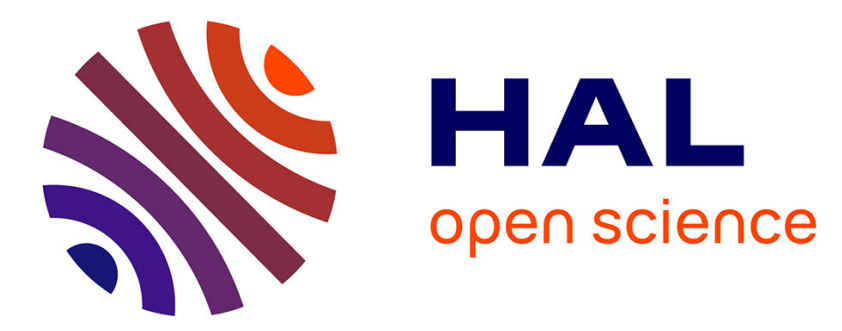

\title{
Better off alone? New insights in the symbiotic relationship between the flatworm Symsagittifera roscoffensis and the microalgae Tetraselmis convolutae
}

Thibault Androuin, Christophe Six, François Bordeyne, Florian de Bettignies, Fanny Noisette, Dominique Davoult

\section{To cite this version:}

Thibault Androuin, Christophe Six, François Bordeyne, Florian de Bettignies, Fanny Noisette, et al.. Better off alone? New insights in the symbiotic relationship between the flatworm Symsagittifera roscoffensis and the microalgae Tetraselmis convolutae. Symbiosis, 2020, 81, p.161-171. 10.1007/s13199-020-00691-y . hal-03019696

\section{HAL Id: hal-03019696 https://hal.science/hal-03019696}

Submitted on 25 Nov 2020

HAL is a multi-disciplinary open access archive for the deposit and dissemination of scientific research documents, whether they are published or not. The documents may come from teaching and research institutions in France or abroad, or from public or private research centers.
L'archive ouverte pluridisciplinaire HAL, est destinée au dépôt et à la diffusion de documents scientifiques de niveau recherche, publiés ou non, émanant des établissements d'enseignement et de recherche français ou étrangers, des laboratoires publics ou privés. 
1 Better off alone? New insights in the symbiotic relationship between the

2 flatworm Symsagittifera roscoffensis and the microalgae Tetraselmis

3

4

5

6 7

8

9

\section{convolutae}

Thibault Androuin ${ }^{1,2}$, Christophe $\mathrm{Six}^{2}$, François Bordeyne ${ }^{2}$, Florian de Bettignies ${ }^{2}$, Fanny Noisette ${ }^{1}$, Dominique Davoult ${ }^{2}$.

${ }^{1}$ Institut des Sciences de la Mer, Université du Québec à Rimouski, 310 Allée des Ursulines, Rimouski, Québec, G5L3A1, Canada

${ }^{2}$ Sorbonne Université, Centre National pour le Recherche Scientifique, Station Biologique de Roscoff, UMR SU-CNRS 7144, 29680 Roscoff, France.

Corresponding author: Thibault Androuin, thibault.androuin01@gmail.com

ORCID: 0000-0001-9310-026X

Short title: Photobiology of Symsagittifera roscoffensis and Tetraselmis convolutae

Keywords: symbiosis, animal-plant, photobiology, Symsagittifera roscoffensis, Tetraselmis convolutae 


\section{Abstract}

24

25

26

27

The acoel flatworm Symsagittifera roscoffensis lives in obligatory symbiosis with the microalgal chlorophyte Tetraselmis convolutae. Although this interaction has been studied for more than a century, little is known on the potential reciprocal benefits of both partners, a subject that is still controversial. In order to provide new insights into this question, we have compared the photophysiology of the freeliving microalgae to the symbiotic form in the flatworm, both acclimated at different light irradiances. Photosynthesis - Irradiance curves showed that the free-living T. convolutae had greater photosynthetic performance (i.e., oxygen production rates, ability to harvest light) than their symbiotic form, regardless of the light acclimation. However, they were affected by photoinhibition under high irradiances, which did not happen for the symbiotic form. The resistance of symbiotic microalgae to photoinhibition were corroborated by pigment analyses, which evidenced the induction of photoprotective mechanisms such as xanthophyll cycle as well as lutein and $\beta$-carotene accumulation. These processes were induced even under low light acclimation and exacerbated upon high light acclimation, suggesting a global stress situation for the symbiotic microalgae. We hypothesize that the internal conditions in the sub-epidermal zone of the flatworm (e.g., osmotic and pH), as well as the phototaxis toward high light imposed by the worm in its environment, would be major reasons for this chronic stress situation. Overall, our study suggests that the relationship between $S$. roscoffensis and $T$. convolutae may be a farming strategy in favor of the flatworm rather than a symbiosis with mutual benefits. 


\section{Introduction}

Symbiosis is an interspecific interaction where two or more organisms live in close association, often supported by a high level of integration of the physiology of both partners (Muscatine 1980). Depending on the benefit reciprocity, symbiosis range along a continuum from parasitism, where one partner benefits at the expense of the other(s), to mutualism, where all partners benefit (Tipton et al. 2019). Symbiosis with photosynthetic microalgae occurs in many groups of marine invertebrates such as Porifera, Cnidaria, Mollusca or Chordata (Venn et al. 2008; Rumpho et al. 2011; Melo Clavijo et al. 2018). Among the most studied animal-algal relationships are the reef-building corals, hosting photosynthetic dinoflagellates in their polyps. More discreet and less known, the flatworm Symsagittifera roscoffensis (Graff 1891) establishes an obligatory symbiosis with the green alga Tetraselmis convolutae (Parke and Manton 1967; Arora 2016; Arboleda et al. 2018). Their interaction is set up at each generation by worm juveniles ingesting microalgae which they will keep for the lifetime of the animal (Keebles 1910). The adult stage does not ingest any organic food and lives autotrophically in the light, in phosphate and nitrate-rich environments, thus depending entirely on the microalgal photosynthetic products (e.g., fatty acid, amino acid, organic acid) (Taylor 1974; Boyle and Smith 1975; Meyer et al. 1979). During the vacuolization process, microalgae lose their cell wall, flagella and eyespot and stay under the epidermis of the worm (Douglas, 1983a). Benefitting the symbiosis, T. convolutae uses the uric acid produced by the worm as an endogenous nitrogen source (Boyle \& Smith, 1975; Douglas, 1983b). This association is not only biologically remarkable but also ecologically relevant, as the flatworm can form large populations on sandy shores, easily noticeable as dark green patches (Keebles 1910; Doonan and Gooday 1982). The exploitation of this ecological niche would generate an annual primary production rates of $872.9 \mathrm{~g} \mathrm{C} \mathrm{m}^{-2}$ (Doonan and Gooday 1982), a value similar to those measured on coral reefs (Muscatine, 1990). Furthermore, the ability of the symbiotic algae to actively uptake nitrates makes $S$. roscoffensis a possible important in situ nitrate interceptor in the sediment at local scales (Carvalho et al. 2013).

In many animal-algal associations (i.e., symbiosis, keptoplasty), the fact that the photosynthetic activity of the algal partner is often increased compared to the free-living form, has led to the "hostmediated enhanced photosynthetic performance' hypothesis (Johnson et al. 2006; Johnson 2011; Serôdio et al. 2014; Decelle et al. 2019). By providing a suitable environment regarding light and nutrient availability, the host may increase the ability of the algae to maximize photosynthetic carbon fixation. In the case of $S$. roscoffensis and T. convolutae, the flatworm can also adjust its position along the vertical light gradient of the sediment photic zone, therefore regulating light acclimation of its symbiont (Serôdio et al. 2011; Worley et al. 2019). It has also been suggested that the typical circular milling of the flatworm, which allow the formation of dense and stable biofilm, may promote the photosynthesis of the microalgae (Sendova-Franks et al. 2018). In their study, Serôdio et al. (2011) suggested that non photochemical quenching of chlorophyll fluorescence (i.e., dissipation of excess 
energy by heat), a mechanism involved in photoprotection, could also play a role in the regulation of light utilization by the symbiotic algae. This ability to maximize the photobiology of the symbiont might constitute a real advantage for $T$. convolutae, in comparison to other free-living forms of non-motile microalgae in intertidal areas. On the other hand, the study of Nissen et al. (2015) demonstrated that the host's reaction to light stimuli was not adjusted to the symbionts' needs, which questions its behavioral capacity of photosynthetic regulation (Serôdio et al. 2011). Considering the lack of evidence for a true mutualistic relationship (sensus Mushegian and Ebert 2015) between S. roscoffensis-T. convolutae (Selosse 2000; Kiers and West 2016), and the somewhat contradictory results about the behavioral photosynthetic regulation of the flatworm (Serôdio et al. 2011; Nissen et al. 2015), more experiment are needed to addressed the benefit of the symbiosis for the algae and a potential exploitative host control by the flatworm.

In this context, the present study assessed the effect of the symbiosis on the photobiology of the microalga Tetraselmis convolutae by comparing the free-living and the symbiotic forms of the alga, acclimated to different light irradiance levels. To do so, we performed oxygen production measurement and pigment analyses in order to understand whether the photosynthesis is increased and/or regulated differently in the host compared to the free-living form.

\section{Material and methods}

\subsection{Biological material and culture conditions}

A strain of the green microalga Tetraselmis convolutae was isolated from one individual of the acoel flatworm Symsagittifera roscoffensis collected on a sandy shore of the French coast of the English Channel (48 $44^{\prime}$ N, $3^{\circ} 59^{\prime} \mathrm{W}$, Roscoff, Brittany, France) on December $7^{\text {th }}, 2007$. A T. convolutae culture was then obtained by micropipette isolation of a single cell released from the specimen. The resulting monoclonal culture was maintained in filter-sterilized seawater supplemented with modified $\mathrm{K} / 2$ medium (-Tris, -Si; Keller et al., 1975) at $17^{\circ} \mathrm{C}$ under a light irradiance of $70-80 \mu$ mol photons $\mathrm{m}^{-2} \mathrm{~s}^{-1}$ in a 12:12 light: dark cycle. The culture was deposited in the Roscoff Culture Collection (http://roscoffculture-collection.org/) as RCC1563.

For the experiment, $T$. convolutae was grown in pyrex erlenmeyer flasks in autoclaved seawater supplemented with $1 \%$ Provasoli solution (Provasoli et al. 1968), in a thermostat-water bath at $19-20^{\circ} \mathrm{C}$. The cultures were acclimated during 8 days to low $\left(30 \mu \mathrm{mol}\right.$ photons $\left.\mathrm{m}^{-2} \mathrm{~s}^{-1}\right)$ and high $(350 \mu \mathrm{mol}$ photons $\mathrm{m}^{-2} \mathrm{~s}^{-1}$ ) white light irradiance upon a 12:12 light: dark cycle, provided by an iodine metal halide light source (400 W, Sylvania, Wilmington, USA). The acclimation time was chosen since it is assumed that light acclimation requires one generation time, which varies between 2 hours and 6 days depending on species and physiology (Reynolds 1984; Grobbelaar et al. 1992; MacIntyre et al. 2002). The irradiance levels were adjusted using a quantameter (Quantum LI-190SA, LiCor, Lincoln, USA) and the distance from the light source. The algal cultures were maintained in exponential growth phase by 
diluting the cultures with fresh medium every two days and monitoring the optical density at $665 \mathrm{~nm}$ with a spectrophotometer (Jenway 6305, JENWAY, Staffordshire, UK). S. roscoffensis were collected on a sandy beach in Roscoff in July 2015 (48 $44^{\prime}$ N, $3^{\circ} 59^{\prime} \mathrm{W}$, Brittany, France) and maintained in the same conditions as described above for the cultures of the free-living microalgae.

\subsection{Oxygen production measurements}

We used a custom-made light chamber to perform oxygen measurements under different light intensities in order to obtain Photosynthesis-Irradiance (P-I) curves. Briefly, this system consisted in a marine water-bath in which the water was maintained at a constant temperature $\left(19-20^{\circ} \mathrm{C}\right)$ with continuously running water. The same white light source as described above was placed above the device and a set of 5 neutral density filters (LEE Filters, Andover, UK) placed between the light source and the aquarium, enabling us to set 8 different irradiance levels (from 0 to $\approx 1200 \mu \mathrm{mol}$ photons $\mathrm{m}^{-2} \mathrm{~s}^{-}$ $\left.{ }^{1}\right)$. Cultures of Tetraselmis convolutae in their growth exponential phase and flatworms (40-50 individuals), along with two controls containing autoclaved seawater, were placed in $2 \mathrm{~mL}$ vials ( 3 and 4 replicates, respectively) and incubated at the different light irradiances. Preliminary experiments allowed the determination of the proper incubation time (30-40 minutes depending on light irradiance) to ensure linear oxygen production/consumption and to avoid Warburg effect (Turner and Brittain 1962).

Oxygen production/consumption rate, translated as net primary production (in the light) and respiration rates (in the dark), were calculated by measuring the dissolved oxygen molar concentration (then converted in mass concentration) at the beginning and the end of the incubation period with a noninvasive optical fiber system (FIBOX 3, PreSens, Regensburg, Germany). The system was calibrated prior to the experiment using sodium dithionite $(0 \%)$ and air bubbling $(100 \%)$. Net oxygen production, respiration and gross oxygen production rates were corrected from controls and calculated as:

$$
\mathrm{R}=\frac{\Delta \mathrm{O} 2 \times \mathrm{V}}{\Delta \mathrm{t} \times \operatorname{chl} a} \quad \mathrm{NP}=\frac{\Delta \mathrm{O} 2 \times \mathrm{V}}{\Delta \mathrm{t} \times \operatorname{chl} a} \quad \mathrm{GP}=\mathrm{NP}-\mathrm{R}
$$

where NP is the net oxygen production rate $\left(\mu \mathrm{g} \mathrm{O}_{2} \mathrm{~h}^{-1} \mu \mathrm{g}\right.$ chl $\left.a^{-1}\right)$, $\mathrm{R}$ the respiration rate $\left(\mu \mathrm{g} \mathrm{O}_{2} \mathrm{~h}^{-1} \mu \mathrm{g}\right.$ $\left.\operatorname{chl} a^{-1}\right)$, GP the gross oxygen production rate $\left(\mu \mathrm{g} \mathrm{O}_{2} \mathrm{~h}^{-1} \mu \mathrm{g} \operatorname{chl~} a^{-1}\right), \Delta \mathrm{O}_{2}$ the difference between initial and final $\mathrm{O}_{2}$ concentrations $\left(\mu \mathrm{g} \mathrm{O}_{2}\right), \mathrm{V}$ the volume of the chamber $(\mathrm{mL}), \Delta \mathrm{t}$ the incubation time $(\mathrm{h})$, and chl $a$ the chl $a$ mass ( $\mu \mathrm{g})$.

At the end of the experiment, the cultures of $T$. convolutae free-living cells were centrifuged at $4500 \times g$ and the supernatant was discarded. For the symbiotic forms, the medium was carefully removed with a micropipette. All samples were then stored at $-20^{\circ} \mathrm{C}$ until further analysis. Pigments were fully extracted in the dark at $4{ }^{\circ} \mathrm{C}$, during $6 \mathrm{~h}$ in $100 \%$ methanol for the free-living cells and $2 \mathrm{~h}$ in $100 \%$ ethanol for the symbiotic forms. Absorbance measurements were made using a spectrophotometer, and chl $a$ was quantified using the Ritchie equations (Ritchie 2008). 


\subsection{HPLC pigment analysis}

A volume of $3 \mathrm{~mL}$ of exponentially growing culture of $T$. convolutae was centrifuged at 4500 $\times g$ and a total of 60 Symsagittifera flatworms by sample were isolated in glass tubes. The cell pellets or the flatworms were resuspended in $100 \%$ acetone for an hour at $-20{ }^{\circ} \mathrm{C}$ and sonicated during 5 rounds of $10 \mathrm{sec}$. The extracts were then centrifuged at $20000 \times \mathrm{g}$, the supernatants collected and centrifuged again to ensure total removal of particles and cell debris. All sample preparations were carried out under subdued light at $4^{\circ} \mathrm{C}$.

The extracts were brought to $25 \%$ Milli-Q water to avoid peak distortion (Zapata and Garrido 1991) and a volume of $100 \mu \mathrm{L}$ of the pigment extract was immediately injected into a High Pressure

161

162

163

164

165 Liquid Chromatography system (Hewlett-Packard HPLC 1100 Series, AGILENT, Santa Clara, USA), equipped with a quaternary pump and diode array detector. Pigment separations were performed using a Waters Symmetry $C_{8}$ column $(150 \times 3 \times 4.6 \mathrm{~mm}, 3.5 \mu \mathrm{m}$ particle size $)$ for $38 \mathrm{~min}$ at a flow rate of 1 $\mathrm{mL} \mathrm{min}^{-1}$, according to procedures previously published (Garrido et al. 2009; Lopes dos Santos et al. 2016). The modified protocol of Garrido et al., (2009) was used in order to allow the separation of neoxanthin and loroxanthin derivatives, with the solutions $\mathrm{A}=$ methanol:acetonitrile:aqueous pyridine solution in the proportions 50:40:10 ( $/ \mathrm{v} / \mathrm{v})$, and $\mathrm{B}=$ acetonitrile:acetone $(80: 20 \mathrm{v} / \mathrm{v})$, following the gradient (min, \%B): $0 \mathrm{~min}, 0 \%$; $22 \mathrm{~min}, 40 \% ; 28 \mathrm{~min}, 95 \%$; $38 \mathrm{~min}, 95 \%$. In order to separate the zeaxanthin from the lutein peak, the classical procedure of Zapata et al., (2000) was also applied for each sample, with the mobile phases $A=$ methanol:acetonitrile:aqueous pyridine solution $(0.025 \mathrm{M})$ in the proportions $50: 25: 25(\mathrm{v} / \mathrm{V} / \mathrm{v})$, and $\mathrm{B}=$ acetonitrile:acetone $(80: 20 \mathrm{v} / \mathrm{v})$, following the same solvent gradient.

Chlorophylls and carotenoids were detected by their absorbance at $440 \mathrm{~nm}$ and identified by diode array spectroscopy. Pigments were identified and, when possible, the relative quantities were estimated using standards derived from macroalgae and phytoplankton cultures by preparative HPLC (Repeta and Bjørland 1997), using previously compiled extinction coefficients (Roy et al. 2011). The deepoxydation state (DES) of the xanthophyll cycle was calculated for each sample as:

$$
\text { DES }=[\text { Zeaxanthin }] /([\text { Violaxanthin }]+[\text { Antheraxanthin }]+[\text { Zeaxanthin }])
$$

\subsection{Statistical analyses}

Oxygen production measurements were normalized to chl $a$ and plotted versus irradiance. The gross oxygen production was preferred to the net oxygen production to take into account the respiration of the flatworm and be able to compare the rates between free-living and symbiotic microalgae forms. Non-linear regression models of photosynthesis considering photoinhibition were fitted to each P-I curve (Platt et al. 1980). Classical photosynthetic parameters were then calculated from the model, including $\mathrm{P}_{\mathrm{MAX}}$ (maximal oxygen production rate), $\alpha$ (initial slope of the curve), $\mathrm{I}_{\mathrm{K}}$ (light intensity at the 
onset of light saturation) and $\beta$ (photoinhibition parameter). $\mathrm{P}_{\mathrm{MAX}}$ was interpreted as the maximum, potential, light-saturated, oxygen production rate under light condition without photoinhibition (Platt et al. 1980).

Two-way factorial analyses of variance (ANOVA) were used to assess differences in model parameters between $T$. convolutae forms (two levels: free-living and symbiotic) and light condition (two levels: low and high light acclimation). When significant, post hoc multiple comparisons were carried out using Tukey HSD. Normality and homocedasticity of the residuals were graphically assessed. When those conditions were not fulfilled, simple factor effect was verified using the non-parametric Wilcoxon test based on ranks. Changes in pigment concentrations were not statistically assessed because only duplicates for free-living cells were available. Statistical analyses were performed in R version 3.3.0 (R Core Team 2016).

\section{Results}

\subsection{Oxygen production measurements}

P-I curves showed clear different shapes between the free-living and the symbiotic forms of Tetraselmis convolutae, for both light irradiance acclimation (Figure 1a \& b). No significant interaction was found between the factors "Living-form" and "Light acclimation" (Table 2).
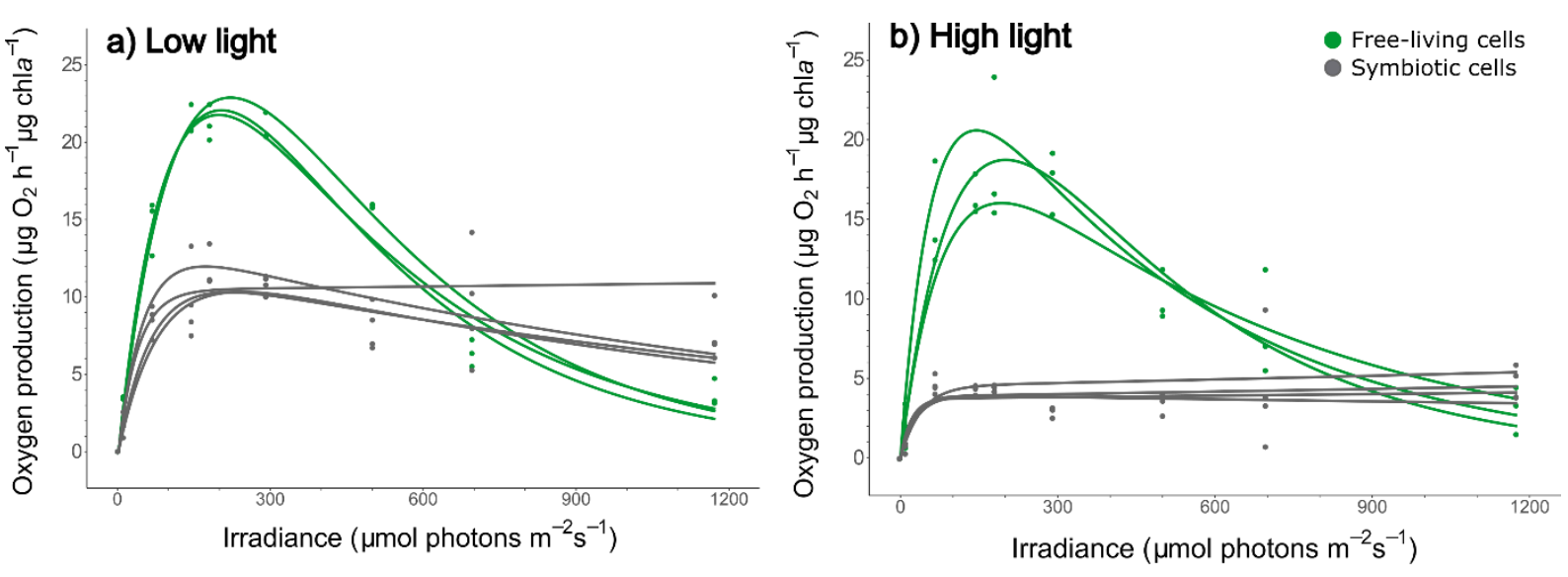

Fig. 1 Photosynthesis-irradiance (P-I) curve of Tetraselmis convolutae in the free-living (green) and symbiotic (grey) forms acclimated under low ( $\mathrm{a} ; 30 \mu \mathrm{mol}$ photons $\mathrm{m}^{-2} \mathrm{~s}^{-1}$ ) and high (b; $350 \mu \mathrm{mol}$ photons $\mathrm{m}^{-2} \mathrm{~s}^{-1}$ ) irradiance.

Overall, the free-living cells exhibited significantly higher values than symbiotic cells for all the photosynthetic parameters calculated: oxygen production rate ( $\mathrm{P}_{\mathrm{MAX}}$ was 3-8 fold higher in free-living cells than symbiotic ones) while the initial slope of the curve $(\alpha)$, and the light intensity at the onset of light saturation $\left(\mathrm{I}_{\mathrm{K}}\right)$ were in average 2-fold greater in free living cells. Conversely the free-living cells showed strong photoinhibition, as evidenced by the significant higher values of photoinhibition index ( $\beta$ : 8-17 fold) (Table $1 \& 2$ ). Indeed, the oxygen production rate of the free living cells cultures strongly 
decreased from about $100 \mu \mathrm{mol}$ photons $\mathrm{m}^{-2} \mathrm{~s}^{-1}$ down to values lower than those of the symbiotic algae. No significant change in respiration rate were detected.

Table 1 Mean $( \pm S D)$ of maximal oxygen production rate $\left(\mathrm{P}_{\mathrm{MAX}}\right)$, initial slope $(\alpha)$, saturation irradiance $\left(\mathrm{I}_{\mathrm{K}}\right)$, photoinhibition index $(\beta)$ and respiration rate $(\mathrm{R})$, in the free-living and symbiotic forms of Tetraselmis convolutae, acclimated to low and high light. $\mathrm{P}_{\mathrm{MAX}}, \alpha, \mathrm{I}_{\mathrm{K}}$ and $\beta$ were retrieved from the model of Platt et al., (1980) whereas $\mathrm{R}$ was experimentally measured.

223

\begin{tabular}{|c|c|c|c|c|}
\hline & \multicolumn{2}{|c|}{ Low light } & \multicolumn{2}{|c|}{ High light } \\
\hline & Free living cells $(n=3)$ & Symbiotic cells $(n=4)$ & Free living cells $(n=3)$ & Symbiotic cells $(n=4)$ \\
\hline $\mathrm{P}_{\mathrm{MAX}}\left(\mu \mathrm{mol} \mathrm{O} \mathrm{O}^{-1} \mu \mathrm{g} \operatorname{chl} a^{-1}\right)$ & $36.1 \pm 3.3$ & $12.4 \pm 1.4$ & $30.9 \pm 3.9$ & $4.0 \pm 0.3$ \\
\hline$\alpha\left(\mu \mathrm{mol} \mathrm{O} \mathrm{h}^{-1} \mu \mathrm{g}\right.$ chla ${ }^{-1} \mu \mathrm{mol}$ photons $\left.\mathrm{m}^{-2} \mathrm{~s}^{-1}\right)$ & $0.31 \pm 0.01$ & $0.22 \pm 0.06$ & $0.33 \pm 0.1$ & $0.15 \pm 0.03$ \\
\hline $\mathrm{I}_{\mathrm{K}}\left(\mu \mathrm{mol}\right.$ photons $\left.\mathrm{m}^{-2} \mathrm{~s}^{-1}\right)$ & $117.1 \pm 5.3$ & $59.5 \pm 19.8$ & $99.3 \pm 24.2$ & $27.9 \pm 7.9$ \\
\hline$\beta\left(\mu \mathrm{mol} \mathrm{O} \mathrm{h}^{-1} \mu \mathrm{g}\right.$ chla $^{-1} \mu \mathrm{mol}$ photons $\left.\mathrm{m}^{-2} \mathrm{~s}^{-1}\right)$ & $0.17 \pm 0.05$ & $0.01 \pm 0$ & $0.08 \pm 0.04$ & $0 \pm 0$ \\
\hline $\mathrm{R}\left(\mu \mathrm{mol} \mathrm{O} \mathrm{h}^{-1} \mu \mathrm{g} \operatorname{chl} a^{-1}\right)$ & $-0.7 \pm 0.4$ & $-1.2 \pm 0.2$ & $0.1 \pm 1.1$ & $-0.2 \pm 0.2$ \\
\hline
\end{tabular}

In terms of light acclimated, only the $\mathrm{I}_{\mathrm{K}}$ parameter and the respiration varied significantly, regardless of the living form (Table 2). Mean $\mathrm{I}_{\mathrm{K}}$ was $84.2 \mu \mathrm{mol}$ photons $\mathrm{m}^{-2} \mathrm{~s}^{-1}$ for low light acclimated algae compared to $58.5 \mu \mathrm{mol}$ photons $\mathrm{m}^{-2} \mathrm{~s}^{-1}$ for high light acclimated ones. Respiration was 14-fold higher in low light acclimated cell than high-light acclimated ones (-0.96 and $-0.07 \mu \mathrm{g} \mathrm{O}_{2} \mathrm{~h}^{-1} \mu \mathrm{g}$ chl $a^{-1}$ respectively).

Table 2 Factorial two-way ANOVA followed by Tuckey HSD post hoc test showing the effect of light condition (low vs. high light acclimation) and living form (free-living vs. symbiotic cells) of the microalgae Tetraselmis convolutae on the initial slope $(\alpha)$, the saturation irradiance $\left(\mathrm{I}_{\mathrm{K}}\right)$ and the respiration rate $(\mathrm{R})$. The effect on the maximal oxygen production rate ( $\left.\mathrm{P}_{\mathrm{MAX}}\right)$, and the photoinhibition index $(\beta)$ was assessed by two distinct Wilcoxon tests. Bold numbers indicate significant level < 0.05. LL: low light, HL: high light, FL: free-living, S: symbiotic.

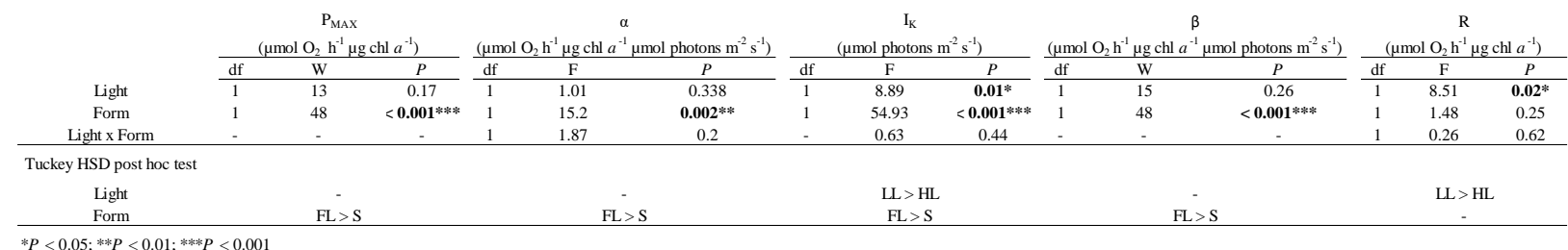

\subsection{HPLC pigment analysis}

The pigments of the free-living form of T. convolutae, i.e. in culture, were difficult to extract, even though we carried out a strong extraction procedure. It displayed a particularly complex pigmentation with the major pigments being typical of Chlorophyta microalgae (similar to the so-called PRASINO-2A group; Roy et al., 2011), notably including chlorophyll $b$, lutein, violaxanthin, cisneoxanthin and loroxanthin (Figure $2 \mathrm{a} \& \mathrm{~b}$, Table 3, Table S1). T. convolutae contain several acylloroxanthin compounds, with the two major ones probably being loroxanthin-decenoate and loroxanthin-dodeceonate as previously reported in several other Tetraselmis species (Garrido et al. 
2009) and in Pyramimonas parkae (Kohata and Watanabe 1989). We also detected a high number of more or less minor pigments. Using the modified method of Garrido et al. (2009), one of them eluted early and showed absorbance properties identical to trans-neoxanthin (peak 1 in Table S1). Two species of carotene were detected in the cell extracts, $\beta, \beta$ - and $\beta, \varepsilon$-carotene but it is probable that other forms co-eluted with them and/or with phaeophytin $a$.
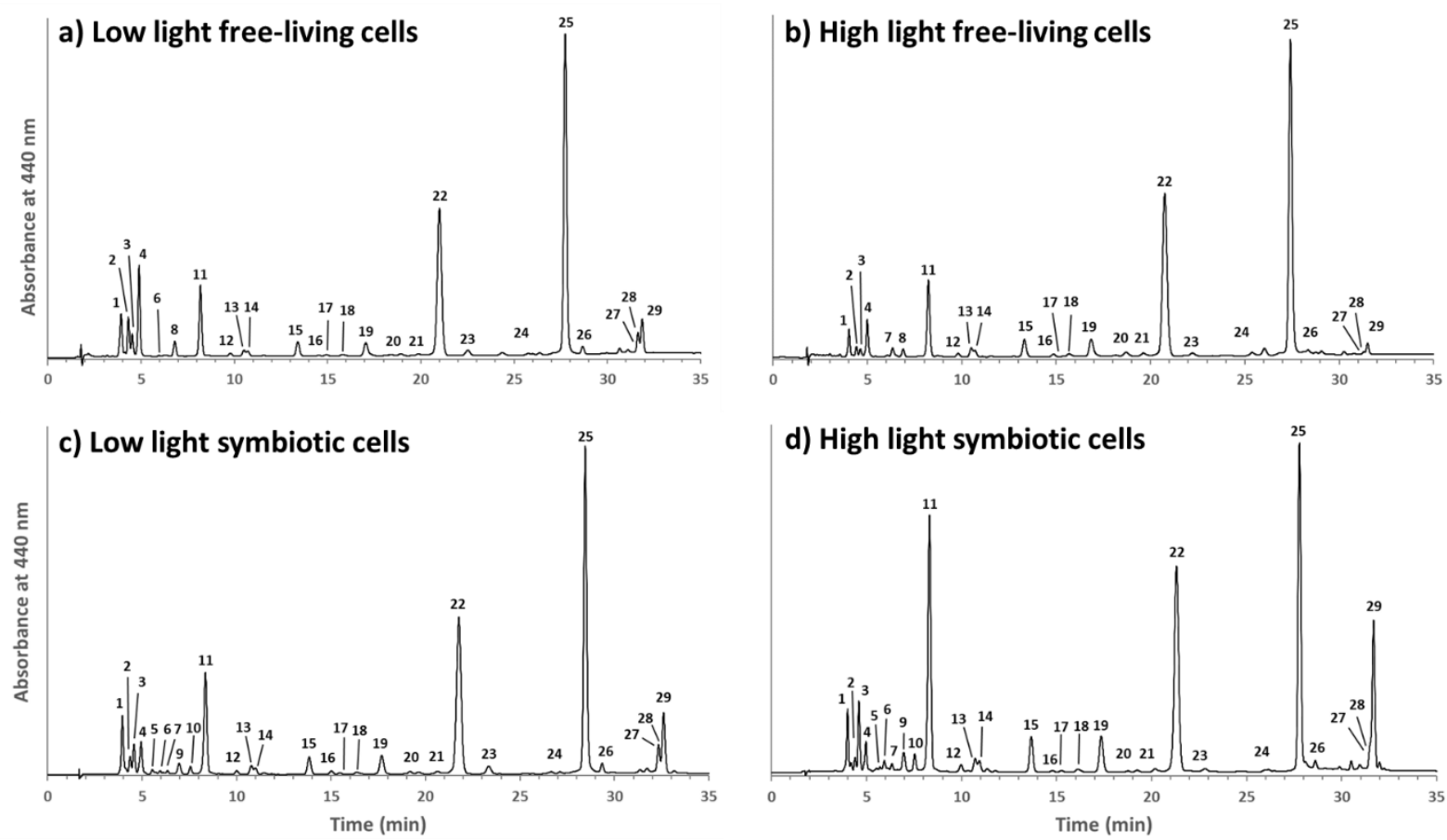

252

253

254

255

256

257

258

259

260

261

262

263

264

265

266

267

Fig. 2 Chromatographic analysis of Tetraselmis convolutae pigmentation (Garrido et al. 2009) as free-living cells acclimated to low (a) and high (b) light, and as a symbiont of Symsagittifera roscoffensis acclimated to low (c) and high (d) light. The retention times and wavelength maxima are mentioned in the supplementary material (Table S1). 1: trans-neoxanthin like; 2: loroxanthin; 3: cis-neoxanthin; 4: violaxanthin; 5: neochrome like; 6: Auroxanthin like; 7: Antheraxanthin; 8: cis-neoxanthin like; 9: Auroxanthin like; 10: Dihydrolutein like; 11: Lutein (+ zeaxanthin); 12: unidentified; 13: unidentified; 14: unidentified; 15: Loroxanthin decenoate; 16: Acyl Loroxanthin like; 17: Unidentified; 18: Unidentified; 19: Loroxanthin dodeceonate; 20: Unidentified; 21: Unidentified; 22: Chlorophyll $b$; 23: Chlorophyll $b$ derivative; 24: Chlorophyll $a$ derivatives; 25: Chlorophyll $a$; 26: Chlorophyll $a$ derivative; 27: $\beta, \varepsilon$-carotene; 28: Phaeophytin $a ; 29$ : $\beta, \beta$-carotene.

In contrast to the cells in culture, we had no difficulty to achieve complete extraction of the pigments for the symbiotic forms. The pigmentation was globally similar to the one of the free-living forms (Figure $2 \mathrm{c} \& \mathrm{~d}$, Table 3). However, a higher proportion of the minor pigments neochrome and auroxanthin was measured in hospite microalgae, whereas these pigments were hardly detectable in the free-living cells. In addition, two other pigments showing wavelength maxima quasi identical to cisneoxanthin and dihydrolutein eluted at about 4.5 and $7.5 \mathrm{~min}$, respectively, only in the symbiotic form (Figure 2c \&d). 
Table 3 Mean $( \pm \mathrm{SD})$ of the major pigments relatively to chlorophyll $a(\mathrm{mg} / \mathrm{g})$ in the free-living and symbiotic forms of Tetraselmis convolutae, acclimated to low and high light. We were not able to quantify all the detected pigments because many of them were in too low amounts to allow purification for calibration of the HPLC system.

Loroxanthin

cis-neoxanthin

Chlorophyll $b$

Loroxanthin decenoate

Loroxanthin dodeceonate

Lutein

$\beta, \beta$-carotene

Violaxanthin

Zeaxanthin

\begin{tabular}{cccc}
\multicolumn{2}{c}{ Low light } & \multicolumn{2}{c}{ High light } \\
\hline Free living cells $(\mathrm{n}=2)$ & Symbiotic cells $(\mathrm{n}=3)$ & Free living cells $(\mathrm{n}=2)$ & Symbiotic cells $(\mathrm{n}=3)$ \\
\hline $9.2 \pm 0.8$ & $4.2 \pm 0.6$ & $2.7 \pm 2.7$ & $2.9 \pm 1.3$ \\
$4.8 \pm 2.2$ & $5.1 \pm 2.7$ & $3.3 \pm 3.3$ & $15.4 \pm 2.8$ \\
$479.5 \pm 18.7$ & $499.3 \pm 67.2$ & $549.4 \pm 32.6$ & $628.5 \pm 32.7$ \\
$6.9 \pm 0.1$ & $7.4 \pm 1.4$ & $11.1 \pm 1.0$ & $16.2 \pm 0.6$ \\
$7.8 \pm 0.2$ & $9.3 \pm 1.2$ & $11.6 \pm 1.1$ & $18.4 \pm 0.8$ \\
$29.5 \pm 2.1$ & $33.4 \pm 4.2$ & $36.6 \pm 2.1$ & $91.0 \pm 8.1$ \\
$7.6 \pm 1.0$ & $12.9 \pm 2.8$ & $3.1 \pm 1.0$ & $43.9 \pm 4.6$ \\
$25.5 \pm 1.3$ & $9.5 \pm 0.1$ & $15.7 \pm 3.7$ & $7.3 \pm 1.1$ \\
$0.3 \pm 0.1$ & $1.8 \pm 0.4$ & $5.3 \pm 1.8$ & $2.7 \pm 0.2$ \\
$0.2 \pm 0.3$ & $4.1 \pm 1.6$ & $2.5 \pm 0.3$ & $11.4 \pm 1.7$
\end{tabular}

276

Acclimation to high light levels induced similar changes in the pigmentation for both free-living and symbiotic forms of $T$. convolutae (Table 3). Several pigments decreased relatively to chlorophyll $a$ in response to high light, including trans-neoxanthin, loroxanthin, cis-neoxanthin (only in the free-living cells), while the chlorophyll $b: a$ ratio remained fairly stable in all conditions. By contrast, the two major acyl-loroxanthin compounds increased in response to high light acclimation. Photoprotective mechanisms such as the xanthophyll cycle were clearly activated (Demmig-Adams and Adams 1996; Jahns and Holzwarth 2012), as shown by the successive deepoxydation of violaxanthin into antheraxanthin and zeaxanthin in both the free-living and symbiotic forms of T. convolutae (Figure 3). This process was accompanied by a significant lutein synthesis (Table 3).

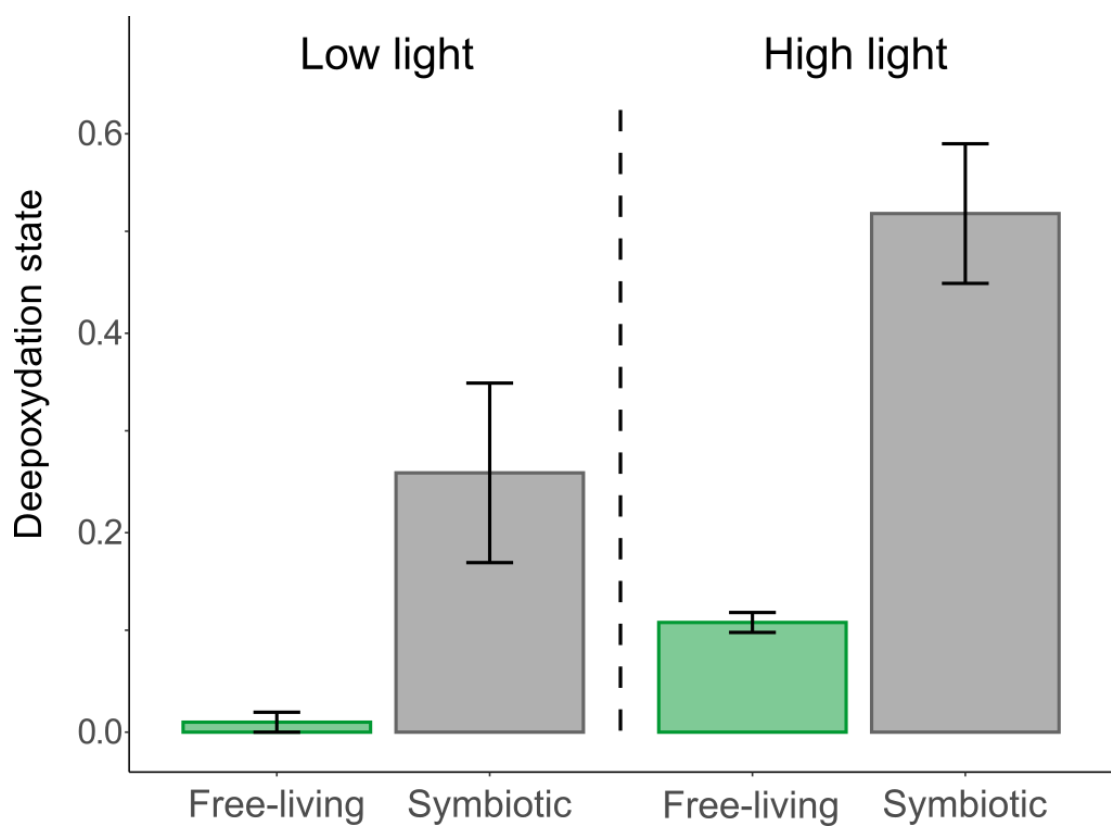

Fig. 3 Deepoxydation state of the xanthophyll cycle in the free-living (green) and symbiotic (grey) forms of Tetraselmis convolutae, acclimated to low and high light (mean $\pm \mathrm{SD}$ ). 
Interestingly, there were clear differences in the amplitude of these acclimation processes between the free-living and the symbiotic cells. Under low light, the symbiotic $T$. convolutae showed much higher levels of the photoprotective pigments lutein, zeaxanthin and $\beta$-carotene. These marked differences were exacerbated under high light acclimation, upon which the symbiotic cells developed high xanthophyll deepoxydation state and a pronounced induction of $c i s$-neoxanthin, lutein along with a strong $\beta$-carotene accumulation.

\section{Discussion}

The symbiosis between the flatworm $S$. roscoffensis and the chlorophyte $T$. convolutae is a remarkable and rare model system that allows studying the level of reciprocity of such interactions (Serôdio et al. 2011; Dupont et al. 2012; Bailly et al. 2014; Nissen et al. 2015; Arboleda et al. 2018). Defining the status of this symbiosis has remained nevertheless challenging. In particular, a number of questions have been recently raised about egalitarian partnerships in nature, with some authors arguing that there is still a lack of evidence for a mutualistic relationship for the S. roscoffensis-T. convolutae couple, especially for the algae, and that the relationship might be considered as a form of imprisonment of the symbiotic partner (Selosse 2000; Kiers and West 2016). In order to give new insights into these questions, we studied the influence of the symbiotic lifestyle on the algal photobiology.

\subsection{The microalgal lifestyle is associated with distinct net oxygen production}

The oxygen production curves measured for both algal forms acclimated to two light irradiance levels, unambiguously showed oxygen production was higher in algal free-living form compared to the symbiotic one, at most of the tested irradiances. The only published data on the oxygen production rate of T. convolutae (Nozawa et al. 1972), using comparable light acclimation (i.e., $73 \mu$ mol photons $\mathrm{m}^{-2} \mathrm{~s}^{-}$

${ }^{1}$ ) and under similar irradiance levels (i.e., 100-200 $\mu$ mol photons $\mathrm{m}^{-2} \mathrm{~s}^{-1}$ ), indicated 3-4 fold lower values than in our study, for both algal living-forms. Since both light during growing and measurement period were overall comparable (estimated by converting the published data, in foot-candle to units of irradiance), the difference could be attributed to the measurement technique (polarographic electrode $v s$. optical fiber). Interestingly, the difference between the two living forms was almost identical. The maximal oxygen production rate modelled (i.e., $\mathrm{P}_{\mathrm{MAX}}$ ) in free-living cells, which occurred between 100 and $200 \mu \mathrm{mol}$ photons $\mathrm{m}^{-2} \mathrm{~s}^{-1}$, was 3 and 8 fold higher at low light and high light, respectively, than in the symbiotic forms, while Nozawa et al. (1972) found a factors of 3 between the two living forms at low light acclimation. To explained this difference, authors proposed that the lower net oxygen production rate observed for the symbiotic form might be due to the host respiration, an increased symbiont photo-respiration, shading effect thanks to the arrangement of the algae within the host, and/or a reduced or host-regulated photosynthetic rate.

Although it is quite possible that the flatworm respired some of the oxygen produced by the alga, it is unlikely that the large differences in oxygen production we observed originated only in the 
worm respiration, especially considering the small differences in the calculated respiration rates. Our data suggest that, although it was not statistically significant, the symbiotic system displays slightly higher respiration rates than the free-living algae alone because of the flatworm respiration, and that the microalgae respired at similar rate in any condition and lifestyle. In addition, the P-I curves of the freeliving and symbiotic alga showed different shapes that are typical of differences in photosynthesis regulation (see below), which would thus be induced by the alga itself.

Our results thus suggest a different perspective to the idea that algal photosynthetic activity would be enhanced in the host (Johnson 2011; Serôdio et al. 2014; Decelle et al. 2019), as the symbiosis would leads here to a decrease of the global photosystem II activity of the microalgal symbiont.

\subsection{Different photoacclimation capacities in different lifestyles}

The different shapes of the oxygen production rate vs. irradiance curves strongly suggest that the algae regulate the photosynthesis process differently depending on the acclimation irradiance and its lifestyle. The symbiotic microalgae showed lower $\alpha$ and $\mathrm{I}_{\mathrm{K}}$ values than the free-living ones, indicating lower efficiency to harvest light and a saturation at lower irradiance level, respectively (Platt et al. 1980; MacIntyre et al. 2002). This is often associated with a reduced functional photosynthetic antenna which, in green algae, is composed of the so-called light harvesting complex proteins. Even though the chl $b: a$ ratio did not change, our results thus suggest a downregulation of at least some of these proteins in the alga in the symbiotic form.

In addition, the symbiotic microalgae were much less sensitive to high light irradiances than the freeliving ones, as indicated by the photoinhibition phenomenon. This photoinhibition suggests a strong photosystem II photoinactivation at irradiances higher than $200 \mu$ mol photons $\mathrm{m}^{-2} \mathrm{~s}^{-1}$ in the free-living cells. These differences between the two lifestyles were exacerbated upon high light acclimation. In particular, when acclimated to $350 \mu \mathrm{mol}$ photons $\mathrm{m}^{-2} \mathrm{~s}^{-1}$, the symbiotic algae were able to maintain a constant photosystem II oxygen evolving up to the highest irradiance tested (i.e. $\approx 1200 \mu$ mol photons $\left.\mathrm{m}^{-2} \mathrm{~s}^{-1}\right)$. These observations suggest that, in contrast to the free-living form, the symbiotic $T$. convolutae may chronically induce photoprotection mechanisms that prevent both photoinhibition and photodamages.

Pigment analyses showed clear differences between the two light irradiance acclimation states in both lifestyles and are globally in agreement with a previous study on Tetraselmis photoacclimation (Garrido et al. 2009). The reduction of some of the pigments in response to high light in both algal forms may be related to a reduction of the functional size of the photosynthetic antenna (Melis et al. 1999).

The most obvious changes concerned the photoprotection mechanisms. High light acclimation resulted in an increase of the photoprotective xanthophyll cycle activity (Demmig-Adams and Adams 1996), indicating an activation of the violaxanthin deepoxydase enzyme in the symbiont plastids. In addition, lutein accumulation was observed in response to high light pre-exposure in both lifestyles. Although the mechanism has not been yet extensively described, this pigment has been shown to be 
induced in response to high light in a number of planktonic chlorophytes (see e.g. Six et al., 2008; Garrido et al., 2009; Lopes dos Santos et al., 2016) and is thought to be involved in photosystem photoprotection (Niyogi et al. 1997; Horton and Ruban 2005; Jahns and Holzwarth 2012). Noteworthy, these photoprotective mechanisms were activated much more intensively in the symbiotic lifestyle than in the free-living microalgae. Indeed, the deepoxydation state of the xanthophyll cycle of the symbiotic algae acclimated to $30 \mu \mathrm{mol}$ photons $\mathrm{m}^{-2} \mathrm{~s}^{-1}$ was twofold higher than the one of free-living algae grown under $350 \mu \mathrm{mol}$ photons $\mathrm{m}^{-2} \mathrm{~s}^{-1}$. Similarly, the lutein accumulation was particularly pronounced in the symbiotic microalgae acclimated to high light. These photoprotection mechanisms were likely associated with non-photochemical quenching of fluorescence, although we did not carry out pulseamplitude modulation (PAM) fluorimetry measurements. At last, the symbiotic microalgae accumulated large amounts of $\beta$-carotene. This is a well-known phenomenon in chlorophytes, which triggers this photoprotective and antioxidant mechanism in response to various types of stresses (Ahmed et al. 2015).

Our results thus suggest that the symbiotic lifestyle is associated with a stress signal in the alga. The fact that such protective mechanisms are induced even under low light suggests that they can be considered as a global stress, which is not necessarily directly linked to light. It is indeed well known that photoprotection can be related and induced by other environmental factors than light, for instance in temperature and osmotic stress situations, with the aim of decreasing the intraplastidial production of reactive oxygen species originating in photosystem II activity (Foyer and Shigeoka 2011). Considering that free-living cells of $T$. convolutae strain RCC1563 were grown since 2007 at a controlled temperature of $17^{\circ} \mathrm{C}$ and that symbiotic cells naturally experienced temperature ranging from $16-22^{\circ} \mathrm{C}$ at the moment of the collection (Doonan and Gooday 1982), the temperature of $20^{\circ} \mathrm{C}$ in our experiment is not considered as stressful.

\subsection{The flatworm as a stressful environment for the symbiotic alga}

As recently observed in planktonic symbiotic Acantharians, the algal symbiont may undergo profound ultrastructural and physiological changes upon inclusion in the host (Decelle et al. 2019). It has been shown that symbiotic Tetraselmis have a different cell structure compare to the free-living cells (Oschman 1966; Provasoli et al. 1968). In particular, the inclusion in the flatworm is associated with the loss of a part of the cell envelope, leading to an intimate contact between the algal plasma membrane and the flatworm internal medium (Douglas 1983b). The large differences in the pigment extraction rates we observed are probably related to the presence of the cell envelope, since the free-living cells were much more difficult to extract. The internal medium of the flatworm might thus constitute a stressful environment for T. convolutae. As already suggested for kleptoplasts in sea slugs (Jesus et al. 2010), the direct contact between the symbiotic algae (then devoid of cell envelope) and the flatworm intern media, which is very different from the seawater, can dramatically change the acido-basic balance of the algal cells. Such drastic medium modification might be considered as a chronic osmotic stress that might activate protective mechanisms in the alga such as, for example, the violaxanthin 
deepoxydase gene and those involved in the lutein synthesis. The accumulation of $\beta$-carotene is also very well-known to occur in osmotic stress situations, notably in Dunaliella salina (Oren 2005). Interestingly, we detected minor amounts of the pigments neochrome and auroxanthin only in the worm samples, whereas these pigments were hardly detectable in the free-living cells. In prasinophytes, these two pigments are often derived from the acidic catalyse of $c i s$-neoxanthin and violaxanthin, respectively (Haugan and Liaaen-Jensen 1994). Even though these two carotenoids might have been synthetized during the pigment extraction, their formation support the idea that the flatworm constitutes a very acidic medium for the marine microalga. In addition, it is worth noting that a previous study also suggested that the flatworm may be a stressful environment for the alga. Indeed, Van Bergeijk and Stal (2001) showed that in hospite algae contain a 6-fold higher concentration of the algal molecule DMSP than in the free-living cells. The induction of this protectant molecule suggests a stress situation for the algae in the flatworm (Dickson and Kirst 1986; Sunda et al. 2002; Archer et al. 2010).

\subsection{From a planktonic to a benthic light niche}

Our results show that, in response to the inclusion in the flatworm, the algae induce permanent light-dissipating photoprotection mechanisms that are typical of a pronounced stress situation. The consequence is that the alga in its symbiotic lifestyle is quite resistant to light stress and is able to maintain photosystem II activity up to high irradiances in spite of a lower photosynthetic efficiency than free-living form. This is likely associated with a lower synthesis of photosynthetic compounds available for the host (Hoogenboom et al. 2006).

The chronic induction of protective mechanism appears to be crucial for the survival of the alga in the flatworm because the symbiosis may be associated, for the alga, to dramatic changes in the osmolarity of its environment but also of its light niche. Indeed, in its planktonic form, T. convolutae deals with light irradiances more or less attenuated in the water column, depending on the depth. By contrast, in the symbiotic lifestyle, the acclimation to light is dependent of $S$. roscoffensis migrations. The flatworms are often observed at the surface of the sediments at low tide and show a positive phototaxis (Doonan and Gooday 1982; Serôdio et al. 2011). This behavior, associated with a shading effect due to the arrangement of the algae within the host (Nozawa et al. 1972), may explain why the symbiotic cells were acclimated to lower light levels than the free-living ones. However, other studies showed that the flatworm could move in areas where the irradiance was higher than optimal for the algae, likely harming their photosynthetic apparatus (Nissen et al. 2015). It is worth noting that during our 8 days of acclimation, the flatworm did not have sediment to potentially escape from the high irradiance provided. However we did observe migration pattern toward less illuminated areas, which is in agreement with the photoaccumulation experiment of Serôdio et al. (2011). The microalgae must then cope with "abnormally" high light irradiances and it is probable that they could not survive without strong photoprotection. Thus, the symbiotic system $S$. roscoffensis $-T$. convolutae appears to use a similar photophysiological strategy as the intertidal diatom-dominated microphytobenthos, which show 
adaptation traits to high irradiances (Cartaxana et al. 2013), while using motility to select the optimal light acclimation (Ezequiel et al. 2015). Our study thus highlights the physiological consequences of a change from a planktonic to a benthic light niche.

\subsection{The flatworm as a parasite of the microalga?}

The traditional ideas behind mutualism are reciprocal benefits and partner cooperation. However, this concept has been revisited for a few years toward a more parsimonious explanation known as exploitative host control (Wooldridge 2010; Lesser et al. 2013; Keeling and McCutcheon 2017). For instance, in Paramecium bursaria and its algal symbiont Chlorella sp., the photosynthetic efficiency of the chlorophyte is higher in the free-living microalgae than in the symbiotic ones. The Chlorella symbionts can escape their host, but only under conditions where the latter does not benefit from symbiosis, and there are no conditions where this nutritional symbiosis is mutually beneficial (Lowe et al. 2016). In the case of the S. roscoffensis - T. convolutae relationship, there is still no observation or evidence for possibility for the microalgae to escape from the flatworm (Muscatine et al., 1974), even though once free (mechanically during our isolation process), the symbiotic algae could recover cell envelope, flagella and eyespot (Ian Probert, person. com.). In addition, our data suggest that the microalgae undergo chronic stress in the flatworm, which induce the locking of the photosynthetic apparatus in photoprotective mode, while the flatworm assimilates photosynthetic compounds from the algae (Taylor 1974; Boyle and Smith 1975; Meyer et al. 1979).

The vertical transmission of symbionts is one important feature that can help understand whether a relationship is mutualistic or parasitic (Garcia and Gerardo 2014). Vertical transmission (i.e., symbionts inherited from parents) is expected to lead to a certain level of phylogenetic homogeneity of the symbionts and to increase symbiont effectiveness for the host (Herre et al. 1999). In the case of $T$. convolutae, algae are ingested as free-living cells by juveniles of S. roscoffensis and are therefore replaced at each generation (i.e., horizontal transmission), impeding any transgenerational selection. Overall, these results question the mutualistic nature of this relationship (Selosse 2000).

The symbiotic association between $S$. roscoffensis and $T$. convoluta could thus be a farming strategy where the flatworm would use the algae to its own needs, without mutualism retribution (Kiers and West 2016; Sørensen et al. 2019). Further research on the molecule exchanges between both partners and on the consequences of the association on the fitness of $T$. convolutae would allow a deeper understanding of the nature of the relationship.

\section{Acknowledgments}

This work was supported by the French program Investissement d'Avenir IDEALG. We thank the Roscoff Aquarium Services, especially Sébastien Henry and Ronan Garnier for their technical help and Xavier Bailly for his advices regarding Symsagittifera roscoffensis ecology and physiology (Research Federation 2424). We thank the Roscoff Culture Collection, in particular Ian Probert, for the 
isolation and maintenance and the Tetraselmis convoluta culture. We also thank Alexandra Michiels for help with R coding, and Francisco Rodriguez and José Luis Garrido for the interesting discussions on the HPLC results. Finally, we are grateful to the anonymous reviewer whose suggestions greatly improved the manuscript.

Authors declare no conflict of interest.

\section{References}

Ahmed F, Fanning K, Netzel M, Schenk PM (2015) Induced carotenoid accumulation in Dunaliella salina and Tetraselmis suecica by plant hormones and UV-C radiation. Appl Microbiol Biotechnol 99:9407-9416. https://doi.org/10.1007/s00253-015-6792-x

Arboleda E, Hartenstein V, Martinez P, et al (2018) An emerging system to study photosymbiosis, brain regeneration, chronobiology, and behavior: the marine acoel Symsagittifera roscoffensis. BioEssays 40:1800107. https://doi.org/10.1002/bies.201800107

Archer SD, Ragni M, Webster R, et al (2010) Dimethyl sulfoniopropionate and dimethyl sulfide production in response to photoinhibition in Emiliania huxleyi. Limnol Oceanogr 55:15791589. https://doi.org/10.4319/lo.2010.55.4.1579

Arora M (2016) Tetraselmis, an introduction. The Botanica 66:155-175

Bailly X, Laguerre L, Correc G, et al (2014) The chimerical and multifaceted marine acoel Symsagittifera roscoffensis: from photosymbiosis to brain regeneration. Front Microbiol 5:498 https://doi.org/10.3389/fmicb.2014.00498

Boyle JE, Smith DC (1975) Biochemical interactions between the symbionts of Convoluta roscoffensis. Proc R Soc Lond [Biol] 189:121-135. https://doi.org/10.1098/rspb.1975.0046

Cartaxana P, Domingues N, Cruz S, et al (2013) Photoinhibition in benthic diatom assemblages under light stress. Aquat Microb Ecol 70:87-92. https://doi.org/10.3354/ame01648

Carvalho LF, Rocha C, Fleming A, et al (2013) Interception of nutrient rich submarine groundwater discharge seepage on European temperate beaches by the acoel flatworm, Symsagittifera roscoffensis. Mar Pollut Bull 75:150-156. https://doi.org/10.1016/j.marpolbul.2013.07.045

Decelle J, Stryhanyuk H, Gallet B, et al (2019) Algal remodeling in a ubiquitous planktonic photosymbiosis. Curr Biol 29:968-978.e4. https://doi.org/10.1016/j.cub.2019.01.073

Demmig-Adams B, Adams WW (1996) The role of xanthophyll cycle carotenoids in the protection of photosynthesis. Trends Plant Sci 1:21-26. https://doi.org/10.1016/S1360-1385(96)80019-7

Dickson DMJ, Kirst GO (1986) The role of $\beta$-dimethylsulphoniopropionate, glycine betaine and homarine in the osmoacclimation of Platymonas subcordiformis. Planta 167:536-543

Doonan S, Gooday G (1982) Ecological studies of symbiosis in Convoluta roscoffensis. Mar Ecol Prog Ser 8:69-73. https://doi.org/10.3354/meps008069

Douglas AE (1983a) Uric acid utilization in Platymonas convolutae and symbiotic Convoluta roscoffensis. J Mar Biol Ass 63:435-447. https://doi.org/10.1017/S0025315400070788 
Douglas AE (1983b) Establishment of the symbiosis in Convoluta roscoffensis. J Mar Biol Ass 63:419-434. https://doi.org/10.1017/S0025315400070776

Dupont S, Moya A, Bailly X (2012) Stable photosymbiotic relationship under $\mathrm{CO}_{2}$-induced acidification in the acoel worm Symsagittifera Roscoffensis. PLoS ONE 7:e29568. https://doi.org/10.1371/journal.pone.0029568

Ezequiel J, Laviale M, Frankenbach S, et al (2015) Photoacclimation state determines the photobehaviour of motile microalgae: The case of a benthic diatom. J Exp Mar Biol Ecol 468:11-20. https://doi.org/10.1016/j.jembe.2015.03.004

Foyer CH, Shigeoka S (2011) Understanding oxidative stress and antioxidant functions to enhance photosynthesis. Plant Physiol 155:93-100. https://doi.org/10.1104/pp.110.166181

Garcia JR, Gerardo NM (2014) The symbiont side of symbiosis: do microbes really benefit? Front Microbiol 5:510 https://doi.org/10.3389/fmicb.2014.00510

Garrido JL, Rodríguez F, Zapata M (2009) Occurence of loroxanthin, loroxanthin decenoate, and loroxanthin dodecenoate in Tetraselmis species (Prasinophyte, Cholorophyta). J Phycol 45:366-374. https://doi.org/10.1111/j.1529-8817.2009.00660.x

Grobbelaar JU, Schanz F, Dubinsky Z, et al (1992) Photosynthetic characteristics of five high light and low light exposed microalgae as measured with ${ }^{14} \mathrm{C}$-uptake and oxygen electrode techniques. Mar Microb Food Webs 6:3-19

Haugan JA, Liaaen-Jensen S (1994) Blue carotenoids. Part 2. The chemistry of the classical colour reaction of common carotoind 5,6-Epoxides with acid. Acta Chem Scand 48:152-159

Herre E, Knowlton N, Mueller U, Rehner S (1999) The evolution of mutualisms: exploring the paths between conflict and cooperation. Trends Ecol Evol 14:49-53. https://doi.org/10.1016/S01695347(98)01529-8

Hoogenboom M, Anthony K, Connolly S (2006) Energetic cost of photoinhibition in corals. Mar Ecol Prog Ser 313:1-12. https://doi.org/10.3354/meps313001

Horton P, Ruban A (2005) Molecular design of the photosystem II light-harvesting antenna: photosynthesis and photoprotection. J Exp Bot 56:365-373. https://doi.org/10.1093/jxb/eri023

Jahns P, Holzwarth AR (2012) The role of xanthophyll cycle and of lutein in photoprotection of photosystem II. Biochim Biophys Acta - Bioenergetics 1817:182-193. https://doi.org/10.1016/j.bbabio.2011.04.012

Jesus B, Ventura P, Calado G (2010) Behaviour and a functional xanthophyll cycle enhance photoregulation mechanisms in the solar-powered sea slug Elysia timida (Risso, 1818). J Exp Mar Biol Ecol 395:98-105. https://doi.org/10.1016/j.jembe.2010.08.021

Johnson MD (2011) The acquisition of phototrophy: adaptive strategies of hosting endosymbionts and organelles. Photosynth Res 107:117-132. https://doi.org/10.1007/s11120-010-9546-8

Johnson MD, Tengs T, Oldach D, Stoecker DK (2006) Sequestration, performance, amd functional control of Cryptophyte plastids in the ciliate Myrionecta rubra (Ciliophora). J of Phycol 42:1235-1246. https://doi.org/10.1111/j.1529-8817.2006.00275.x

Keebles F (1910) Plant Animals, A Study in Symbiosis, Cambridge: University press. Cambridge, $\mathrm{UK}$ 
Keeling PJ, McCutcheon JP (2017) Endosymbiosis: The feeling is not mutual. J Theor 434:75-79. https://doi.org/10.1016/j.jtbi.2017.06.008

Keller MD, Selvin RC, Claus W, Guillard RRL (1975) Media for the culture of oceanic ultraplankton. J Phycol 23:633-638

Kiers ET, West SA (2016) Evolution: welcome to symbiont prison. Curr Biol 26:R66-R68. https://doi.org/10.1016/j.cub.2015.12.009

Kohata K, Watanabe M (1989) Diel changes in the composition of photosynthetic pigments and cellular carbon and nitrogen in Pyramimonas parkeae (Prasinophyte). J Phycol 25:377-385

Lesser MP, Stat M, Gates RD (2013) The endosymbiotic dinoflagellates (Symbiodinium sp.) of corals are parasites and mutualists. Coral Reefs 32:603-611. https://doi.org/10.1007/s00338-013$1051-\mathrm{z}$

Lopes dos Santos A, Gourvil P, Rodríguez F, et al (2016) Photosynthetic pigments of oceanic Chlorophyta belonging to prasinophytes clade VII. J Phycol 52:148-155. https://doi.org/10.1111/jpy.12376

Lowe CD, Minter EJ, Cameron DD, Brockhurst MA (2016) Shining a light on exploitative host control in a photosynthetic endosymbiosis. Curr Biol 26:207-211. https://doi.org/10.1016/j.cub.2015.11.052

MacIntyre HL, Kana TM, Anning T, Geider RJ (2002) Photoacclimation of photosynthesis irradiance response curves and photosynthetic pigments in microalgae and cyanobacteria. J Phycol 38:17-38. https://doi.org/10.1046/j.1529-8817.2002.00094.x

Melis A, Neidhardt J, Benemann JR (1999) Dunaliella salina (Chlorophyta) with small chlorophyll antenna sizes exhibit higher photosynthetic productivities and photon use efficiencies than normally pigmented cells. J Appl Phycol 10:515-525

Melo Clavijo J, Donath A, Serôdio J, Christa G (2018) Polymorphic adaptations in metazoans to establish and maintain photosymbioses: Evolution of photosymbiosis. Biol Rev 93:20062020. https://doi.org/10.1111/brv.12430

Meyer H, Provasoli L, Meyer F (1979) Lipid biosynthesis in the marine flatworm Convoluta roscoffensis and its algal symbiont Platymonas comvoluta. Biochim Biophys Acta 573:464480

Muscatine L (1980) Productivity of zooxanthellae. In: Primary productivity in the sea, Plenum. P.G. Falkowski, New York

Muscatine L (1990) The role of symbiotic algae in carbon and energy flux in reef corals. In: Coral Reefs, Elsevier. Z. Dubinsky, Amsterdam

Muscatine L, Elizabeth Boyle J, Smith DC (1974) Symbiosis of the acoel flatworm Convoluta roscoffensis with the alga Platymonas convolutae. Proc R Soc Lond [Biol] 187:221-234

Mushegian AA, Ebert D (2015) Rethinking "mutualism" in diverse host-symbiont communities. BioEssays 38:100-108. https://doi.org/10.1002/bies.201500074

Nissen M, Shcherbakov D, Heyer A, et al (2015) Behaviour of the plathelminth Symsagittifera roscoffensis under different light conditions and the consequences for the symbiotic algae Tetraselmis convolutae. J Exp Biol 218:1693-1698. https://doi.org/10.1242/jeb.110429 
Niyogi KK, Bjorkman O, Grossman AR (1997) The roles of specific xanthophylls in photoprotection. Proc Natl Acad Sci USA 94:14162-14167. https://doi.org/10.1073/pnas.94.25.14162

Nozawa K, Taylor DL, Provasoli L (1972) Respiration and photosynthesis in Convoluta roscoffensis Graff, infected with various symbionts. Biol Bull 143:420-430

Oren A (2005) A hundred years of Dunaliella research: 1905-2005. Saline Syst 1:1-14. https://doi.org/10.1186/1746-1448-1-2

Oschman JL (1966) Development of the symbiosis of Convoluta roscoffensis Graff and Platymonas sp. J Phycol 2:105-111

Parke M, Manton I (1967) The specific identity of the algal symbiont in Convoluta roscoffensis. J Mar Biol Ass 47:445-464

Platt T, Gallegos CL, Harrison WG (1980) Photoinhibition of photosynthesis in natural assemblages of marine phytoplankton. J Mar Res 38:103-111

Provasoli L, Yamasu T, Manton FRS (1968) Experiments on the resynthesis of symbiosis in Convoluta roscoffensis with different flagellate cultures. J Mar Biol Ass 48:465-479

R Core Team (2016) R: a language and environment for statistical computing. R Foundation for Statistical Computing, Vienna, Austria

Repeta DJ, Bjørland T (1997) Preparation of carotenoids standards. In: Phytoplankton Pigments in Oceanography, UNESCO Publishing. Jeffrey SW, Mantoura RFC, Wright SW, Paris

Reynolds CS (1984) The ecology of freshwater phytoplankton., Cambridge University Press. Cambridge, UK

Ritchie RJ (2008) Universal chlorophyll equations for estimating chlorophylls $a, b, c$, and $d$ and total chlorophylls in natural assemblages of photosynthetic organisms using acetone, methanol, or ethanol solvents. Photosynthetica 46:115-126. https://doi.org/10.1007/s11099-008-0019-7

Roy S, Llewellyn CA, Egland ES, Johnsen G (2011) Phytoplamkton Pigments, Characterization, Chemotaxonomy, and Applications in Oceanography, Cambridge University Press. Cambridge, UK

Rumpho ME, Pelletreau KN, Moustafa A, Bhattacharya D (2011) The making of a photosynthetic animal. J Exp Biol 214:303-311. https://doi.org/10.1242/jeb.046540

Selosse M-A (2000) Un exemple de symbiose algue-invertébré à Belle-Isle-en-Mer: la planaire Convoluta roscoffensis et la prasinophycée Tetraselmis convolutae. Acta Bot Gallica 147:323-331. https://doi.org/10.1080/12538078.2000.10515864

Sendova-Franks AB, Franks NR, Worley A (2018) Plant-animal worms round themselves up in circular mills on the beach. R Soc open sci 5:180665. https://doi.org/10.1098/rsos.180665

Serôdio J, Cruz S, Cartaxana P, Calado R (2014) Photophysiology of kleptoplasts: photosynthetic use of light by chloroplasts living in animal cells. Phil Trans R Soc B 369:20130242. https://doi.org/10.1098/rstb.2013.0242

Serôdio J, Silva R, Ezequiel J, Calado R (2011) Photobiology of the symbiotic acoel flatworm Symsagittifera roscoffensis: algal symbiont photoacclimation and host photobehaviour. J Mar Biol Ass 91:163-171. https://doi.org/10.1017/S0025315410001001 
Six C, Finkel ZV, Rodríguez F, et al (2008) Contrasting photoacclimation costs in ecotypes of the marine eukaryotic picoplankter Ostreococcus. Limnol Oceanogr 53:255-265. https://doi.org/10.4319/lo.2008.53.1.0255

Sørensen MES, Lowe CD, Minter EJA, et al (2019) The role of exploitation in the establishment of mutualistic microbial symbioses. FEMS Microbiol Lett 366:fnz148. https://doi.org/10.1093/femsle/fnz148

Sunda W, Kieber DJ, Kiene RP, Huntsman S (2002) An antioxidant function for DMSP and DMS in marine algae. Nature 418:317-320. https://doi.org/10.1038/nature00851

Taylor DL (1974) Nutrition of algal-invertebrate symbiosis. I. Utilization of soluble organic nutrients by symbiont-free hosts. Proc R Soc Lond [Biol] 186:357-368

Tipton L, Darcy JL, Hynson NA (2019) A developing symbiosis: enabling cross-talk between ecologists and microbiome scientists. Front Microbiol 10:292. https://doi.org/10.3389/fmicb.2019.00292

Turner JS, Brittain EG (1962) Oxygen as a factor in photosynthesis. Biol Rev 37:130-170

Van Bergeijk SA, Stal LJ (2001) Dimethylsulfoniopropionate and dimethylsulfide in the marine flatworm Convoluta roscoffensis and its algal symbiont. Mar Biol 138:209-216

Venn AA, Loram JE, Douglas AE (2008) Photosynthetic symbioses in animals. J Exp Bot 59:10691080. https://doi.org/10.1093/jxb/erm328

Wooldridge SA (2010) Is the coral-algae symbiosis really 'mutually beneficial' for the partners? Bioessays 32:615-625. https://doi.org/10.1002/bies.200900182

Worley A, Sendova-Franks AB, Franks NR (2019) Social flocculation in plant-animal worms. R Soc open sci 6:181626. https://doi.org/10.1098/rsos.181626

Zapata M, Garrido JL (1991) Influence of injection conditions in reversed-phase high-performance liquid chromatography of chlorophylls and carotenoids. Chromatographia 31:589-594

Zapata M, Rodríguez F, Garrido JL (2000) Separation of chlorophylls and carotenoids from marine phytoplankton; a new HPLC method using a reversed phase $\mathrm{C}_{8}$ column and pyridine containing mobile phases. Mar Ecol Prog Series 195:29-45 


\section{Supplementary material}

664 Table S1: Chromatogram peak identification, retention time and online spectral characteristics of the pigments

665 detected with the modified method of Garrido et al. (2009) in the free-living and symbiotic forms of Tetraselmis 666 convolutae.

667

\begin{tabular}{|c|c|c|c|c|c|}
\hline \multirow{2}{*}{$\frac{\text { Peak \# }}{1}$} & \multirow{2}{*}{$\begin{array}{c}\text { Pigment } \\
\text { trans - neoxanthin } \\
\text { like }\end{array}$} & \multirow{2}{*}{$\frac{\text { Retention time (min) }}{3.85}$} & \multicolumn{3}{|c|}{ Wavelength maxima (nm) } \\
\hline & & & 418 & 442 & 471 \\
\hline 2 & Loroxanthin & 4.21 & (423) & 447 & 474 \\
\hline 3 & cis -neoxanthin & 4.48 & 414 & 438 & 466 \\
\hline 4 & Violaxanthin & 4.86 & 414 & 441 & 470 \\
\hline 5 & Neochrome like & 5.74 & 400 & 423 & 450 \\
\hline 6 & Auroxanthin like & 5.94 & 381 & 402 & 427 \\
\hline 7 & Antheraxanthin & 6.35 & (423) & 448 & 475 \\
\hline 8 & cis -neoxanthin like & 4.48 & 413 & 437 & 465 \\
\hline 9 & Auroxanthin like & 6.96 & 381 & 402 & 427 \\
\hline 10 & Dihydrolutein like & 7.53 & 406 & 430 & 455 \\
\hline 11 & Lutein (+ zeaxanthin) & 8.31 & (422) & 447 & 475 \\
\hline 12 & Unidentified & 10 & 423 & 441 & 468 \\
\hline 13 & Unidentified & 10.73 & (422) & 443 & 471 \\
\hline 14 & Unidentified & 10.85 & (421) & 443 & 469 \\
\hline 15 & $\begin{array}{l}\text { Loroxanthin } \\
\text { decenoate }\end{array}$ & 11.51 & (424) & 449 & 475 \\
\hline 16 & Acyl Loroxanthin like & 12.56 & (424) & 449 & 475 \\
\hline 17 & Unidentified & 15.49 & (423) & 444 & 472 \\
\hline 18 & Unidentified & 16.41 & (423) & 445 & 470 \\
\hline 19 & $\begin{array}{l}\text { Loroxanthin } \\
\text { dodeceonate }\end{array}$ & 17.81 & (424) & 449 & 476 \\
\hline 20 & Unidentified & 19.25 & (424) & 448 & 477 \\
\hline 21 & Unidentified & 20.59 & (423) & 444 & 472 \\
\hline 22 & Chlorophyll $b$ & 21.71 & 464 & 600 & 649 \\
\hline 23 & $\begin{array}{c}\text { Chlorophyll } b \\
\text { derivative }\end{array}$ & 23.3 & 463 & 599 & 649 \\
\hline 24 & $\begin{array}{c}\text { Chlorophyll } a \\
\text { derivatives }\end{array}$ & $24-27$ & 430 & 617 & 663 \\
\hline 25 & Chlorophyll $a$ & 28.24 & 431 & 617 & 663 \\
\hline 26 & $\begin{array}{c}\text { Chlorophyll } a \\
\text { derivative }\end{array}$ & 29.35 & 433 & 617 & 663 \\
\hline 27 & $\beta, \varepsilon$-carotene & 32.33 & (424) & 448 & 476 \\
\hline 28 & Phaeophytin $a$ & 32.42 & 410 & 608 & 666 \\
\hline 29 & $\beta, \beta$-carotene & 32.59 & (427) & 453 & 478 \\
\hline
\end{tabular}

